\title{
Scaling-up the Production of $13 S$-Hydroxy-9Z,11E-octadecadienoic Acid (13S-HODE) through Chemoenzymatic Technique
}

\author{
Muhammad Nor Omar, Humphrey Moynihan, ${ }^{* 1}$ and Richard Hamilton ${ }^{\text {th2 }}$ \\ Malassian Palm Oil Board (MPOB), P.O. Box 10620, 50720 Kuala Lampar. Malaysia \\ "Schoof of Phamacy and Chemistry, Liverpool John Moores Unversity', Bwom Street, Liverpool L3 $3 A F$, UK \\ Received June 29, 2002
}

Key Words : Scale-up, 13S-HIODE, Chemoenzymatic technique

In spite of greater use of oils and lats in the lood industry, the other applications have not been explored very much. Beside the oleochemical industry, the other areas that attract greater interest nowadays are the utilization of latly acids and heir derivatives in pharmaceutical applications. While most fatly acids are achiral molecules, this lack of chirality becomes a great challenge to the chemists to look into possibilities of transforming them into highly value-added chiral molecules which exhibil a vast varicty of biological roles in plants and mammals. The most popular technique to transform achiral latly acids into their corresponding chiral metabolites is through biotechnology processes. ${ }^{\text {' With the }}$ increasing demands for microbial and enzymatic biotransformation, the search for new biologically active substances has been given great attention. In the case of linoleic acid $\mathbf{1}$ the enzyme which can transform the acid into a chiral hydroperoxide, i.e. 13S-hydroperoxy-9Z,11E-octadecadienoic acid (I3S-IIPOD, 2) is called lipoxygenase (LOX). 13SIIPOD is a precursor for the formation of I $3 S$-hydroxy9Z,1IE-octadecadicnoic acid (13S-J IODE, 3) (Scheme 1).

13S-IJODE 3 is an important chiral molecule because it shows a vast varicty of biological effects in plants and mammals. In mammals, 13S-IJODE exhibits calcium ionophoric propertics. ${ }^{2}$ decreases platelet adhesion to endothelial cell and maintains the thromboresistance of vascular endothelium." Meanwhilc, in plants, I3.S-IJODE exhibits anti-

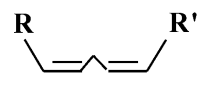

1

$\mathrm{R}: \mathrm{C}_{7} \mathrm{H}_{14} \mathrm{COOH}$

$\mathrm{R}^{\prime}: \mathrm{C}_{5} \mathrm{II}_{11}$

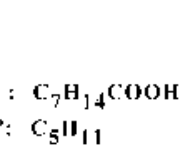

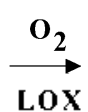

LOX

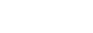

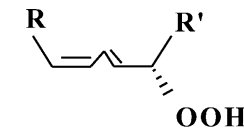

2

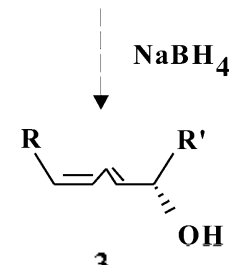

3

Scheme 1

"Present address: Department of Chemistry. University College Cork, Cork, Ireland

${ }^{2}$ Present address: 10. Vorris Way, Formby, Mersey side. I,iverpool I,37 8I313, UK fungal activities and serves as precursor in the formation of cutin." the protective layer of plants against pathogenic attacks. Beside that, I3S-IJODE is also utilized as a starting material for the production of an unsaturated macrocyclic C13 lactone ${ }^{6}$ and other biologically active molecules. Due to ever increasing demand for 13S-IJODE 3 as the starting material for organic syntheses. the scaling-up production of this compound from milligram to gram scale would become our main synthetic target.

Several steps have been taken to increase the production of 2 and 3 at milligram scale. ${ }^{6-11}$ Gardner and New1on have successlully produced $600 \mathrm{mg}$ of $13 S$-IJPOD 2 from $800 \mathrm{mg}$ of linoleic acid 1 using $10 \mathrm{mg}$ soybcan LOX, cooled at $0^{\circ} \mathrm{C}$ and bubbled with pure oxygen al pII 10. To improve solubility of oxygen. lacazio $e t$ at. ${ }^{8}$ have used oxygen under 4 atm pressure in an aqueous buffer solution which was cooled at $0-4{ }^{\circ} \mathrm{C}$. Meanwhile, Srinivasulu and $\mathrm{Rao}^{9} \cdot 10$ have utilized detergent and alcohol in order to lacilitate the solubility of the substrate. Organic solvents such as isooctane and dimethyl sulfoxide (DMSO) have also been used by Emken and Dutton" 10 improve oxygen solubility as well as to increase substrate concentration. Recently, immobilized lipoxygenase (LOX) on various supports has been employed with the aim of increasing the yield and for multiple uses of the enzyme. Maguire $e t a l^{6}$ have oblained the hydroperoxide in high yield by immobilizing LOX on oxirane acrylic beads in phosphate buffer al pl 7.5 and then storing al $4^{\circ} \mathrm{C}$ for 60 hrs prior to use. In our work, the conversion of 1 at milligram scale ( $800 \mathrm{mg} / \mathrm{L})$ using immobilized soy LOX-IB followed the same procedure as reported earlier ${ }^{6}$ with a slight modification. I1 was found that the yield of $3(75.8 \%)$ was comparable to the result oblained by previous researcher (ite. $77 \%)$. The spectroscopic data (IR. 'II NMR, and MS) supported by specilic rotation $[\alpha \mid$ conlirmed the presence of 3. Ilowever, the yield of 3 decreased when the concentration of 1 was increased to $5 \mathrm{~g} / \mathrm{L}$ during the scaling-up process even the immobilized LOX concentration was increased from $70 \mathrm{mg} / \mathrm{L}$ to $100 \mathrm{mg} / \mathrm{L}$. Although with the addition of DMSO, the yield was still below the expected value (i.e. $75.8 \%$ ). I1 showed that the higher the concentration of 1 might retard the activity of LOX even though the LOX concentration was increased.

The scaling-up production of $13 S$-I IODE 3 using linoleic acid $(1,5 \mathrm{~g} / \mathrm{L})$ and incubating with soy lipoxygenase LOX- 
Table 1. Scaling-up the production of 1.35 -1101)l 3

\begin{tabular}{lc}
\hline Experiment & Yield $\left({ }^{0}{ }^{0}\right)$ \\
\hline I.OX & 48.3 \\
I.OX and J)MSO & 56.2 \\
Immobilized I.OX & 59.6 \\
Immobilized I.OX and J)MSO & 68.5 \\
\hline
\end{tabular}

IB gave 3 in $48.3 \%$ yield, while the incubation with the addition of DMSO improved the yield of 3 to $56.2 \%$ (Table 1). It showed that the addition of DMSO increased the solubility of oxygen and the concentration of 1 in buffer solution. " As a result, more contersion of 1 to 2 would take place and hence improved the yield of $\mathbf{3}$. Although the use of immobilized LOX without the addition DMSO gave a better yield $(59.6 \%)$ than the combined LOX and DMSO. the best yield (i.e. $68.5 \%$ ) was obtained when the combined immobilized LOX and DMSO were used However the concentration of DMSO should be kept between 10 to $20 \%$ in order to aroid the inhibition of the activity of the enzy me $e^{9-1]}$ due to the excessive use of the solvent. ${ }^{9-11}$ In conclusion, the scalingup procedure using the immobilized LOX-1B with added DMSO afforded a sufficient amount of 3 which could be used as an important cliral source for further transformation into the other biologically active molecules. ${ }^{\text {' }}$

\section{Experimental Section}

Optical rotation was recorded on Model D Polarimeter (Bellingham \& Stonlev; $C K$ ) and the sample was dissolved in chloroform. TLC was performed on pre-coated silica gel G60 $(0.2 \mathrm{~mm}$. Merch) with solvent system of diethyl ether in $n$-hexane containing $1 \%$ glacial acetic acid. The plate was developed by dipping into a solution of $p$-anisaldehyde ( 1 $\mathrm{mL}$. Sigma) and sulphuric acid ( $2 \mathrm{~mL})$ in methanol $(100 \mathrm{~mL})$ and heated at $110^{\circ} \mathrm{C}$ for $1 \mathrm{~min}$. Silica gel column chromatograply was performed using silica gel G60 (70-230 mesh. Merck) and the sample was eluted with diethyl ether in hexane with the addition of glacial acetic acid. The fractions collected were evaporated under $\mathrm{N}_{2}$ and monitored by thinlayer chromatography (TLC) and gas chromatography (GC). The GC analyses were performed on a Philips PU 4600 gas chromatograph using capillary column (DBI. $30 \mathrm{~m} \times 0.32$ mm. i.d. $\times 1 \mu \mathrm{m}, J \& I^{\prime}$ Scientific, $(K)$ ) and equipped with flame ionization detector (FID). The hydrogen was used as carrier gas and flowed under $60 \mathrm{kPa}$ head columm pressure. The detector and injector temperatures were $300^{\circ} \mathrm{C}$ and 280 " $\mathrm{C}$ respectively and the column temperature was programmed from $90{ }^{\circ} \mathrm{C}$ to $300^{\circ} \mathrm{C}$ at $+{ }^{\circ} \mathrm{C} \mathrm{min}^{-1}$. The sample was correrted into trimethylsily 1 ether by treating the sample with N,O-bis(trimethy lsily 1)-trifluoroacetanide (BSTFA). heated at $60^{\circ} \mathrm{C}$ for $15 \mathrm{~min}$ prior to $\mathrm{GC}$ analysis. The chromatograms and results were recorded using a Spectra Physics SP 4600 integrator. IR spectra were analysed on a Perkin-Elmer 1600 series FTIR grating spectrophotometer. 'H NMR spectra were recorded on a JEOL JNM-FXY0Q FTNMR spectrometer operating at $90 \mathrm{MHz}$. Samples were dissolved in $\mathrm{CDCl}_{3}$ and chemical shifts $\left(\delta_{1}\right)$ were reported in ppm downfield from tetramethylsilane (TMS). The coupling constants $(J)$ were quoted in $\mathrm{Hz}$. Mass spectra were provided by the EPSR National Mass Spectrometry Centre. The Department of Chemistry, University of Swansea.

13S-HODE 3 was prepared in milligram scale according to the previous method "with a slight modification. Briefly. the immobilized soybean lipoxygenase type $1 B(70 \mathrm{mg}$. Sigma) on oxirane acrylic beads ( $3 \mathrm{~g} .150 \mu$. Sigma) was suspended in $0.1 \mathrm{M}$ borate buffer $(800 \mathrm{~mL}, \mathrm{pH} 9.5)$ and cooled at $0^{\circ} \mathrm{C}$. While stirring. the suspension was added portionwise the emulsion of 1 (3.10 mmol in $0.1 \mathrm{M}$ borate buffer). Then. the emulsion mixture was bubbled with oxygen and the reaction was monitored by gas chronatograplic analysis (GC) at every 15 min incubation time. After one and halfhour the mixture was acidified to $\mathrm{pH} 3$, saturated with sodium chloride and extracted with diethyl ether $(200 \mathrm{~mL})$. The ethereal layer was dried and evaporated in racto to afford the crude hydroperoxide 2 . The crude product was dissolved in methanol $(30 \mathrm{~mL})$. stirred and reduced with $\mathrm{NaBH}_{1}(25 \mathrm{mmol})$ at $0^{\circ} \mathrm{C}$ for $20 \mathrm{~min}$. Then. the reaction product was acidified to $\mathrm{pH} 3$, diluted with water $(200 \mathrm{~mL})$ and extracted with diethyl ether $(100 \mathrm{~mL})$. The combined ethereal layer was dried and concentrated in racuo. The crude product was purified by silica gel column chromatography using $30 \%$ diethyl ether in $n$-hexane containing $1 \%$ glacial acetic acid to afford I3S-HODE (3) $(2.35 \mathrm{mmol} .75 .8$ $\%$ yield) as a colourless oil $\left[\mathrm{R}_{i}=0.61\right.$ (TLC. $\left.\left.40 \% \mathrm{Et}_{2} \mathrm{O}\right)\right]$; $|\alpha|_{D}+9.6^{\circ}\left(c 0.6 . \mathrm{CHCl}_{3}\right):$ IR (neat) $\mathrm{cm}^{-1}: 3443.2997 .2920$. $28+5,1707.896 ; \delta_{11}$ ppm: $0.91\left(3 \mathrm{H}, \mathrm{t.} \mathrm{CH}_{3}\right), 1.26-1.68(18 \mathrm{H}$, m. $\left.\mathrm{CH}_{2}\right), 2.20\left(2 \mathrm{H}, \mathrm{m}, 8-\mathrm{CH}_{2}\right) .2 .36\left(2 \mathrm{H}, \mathrm{t}, 2-\mathrm{CH}_{2}\right), 4.10$ (IH. m. H-13), $5.4 \mathrm{l}(\mathrm{lH} . \mathrm{t} . J=10.7 \mathrm{~Hz}, \mathrm{H}-9) .5 .70(\mathrm{lH} . \mathrm{m}$. $\mathrm{H}-\mathrm{I} 2), 5.80\left(2 \mathrm{H}, \mathrm{s}, \mathrm{OH}\right.$ and $\left.\mathrm{CO}_{-} \mathrm{H}\right) .5 .93(\mathrm{lH} . \mathrm{d}, \mathrm{H}-10) .6 .43$ (2H. $\mathrm{ml}, J=15.3 \mathrm{~Hz}, \mathrm{H}-\mathrm{Il}$ )]: $\mathrm{MS}(\mathrm{EI}) \mathrm{m} / \mathrm{z} 73,74,173,225$. $293,295,311,367,382,383$

\section{Scaling-up the production of 13 S-HODE}

Production of 13S-HODE using LOX. Soybean liposygentase type IB ( $100 \mathrm{mg}$ ) was suspended in $0.1 \mathrm{M}$ borate buffer $(800 \mathrm{~mL}, \mathrm{pH} 9.5)$. stirred and cooled at $0{ }^{\circ} \mathrm{C}$. The cooled suspension was added portionwise the emulsion of 1 (17.8 mmol) in $0.1 \mathrm{M}$ borate buffer $(200 \mathrm{~mL}, \mathrm{pH} 9.5)$ and the mixture was bubbled with oxygen. The corversion of 1 was monitored by gas chromatographic analy sis (GC) at every 15 min incubation time. After $2 \mathrm{~h}$. the reaction mixture was acidified to $\mathrm{pH} 3$. saturated with $\mathrm{NaCl}$ and extracted with diethyl ether $(250 \mathrm{~mL})$. The ethereal laver was dried and concentrated in racto. The residue was dissolved in methanol $(100 \mathrm{~mL})$, cooled at $0^{\circ} \mathrm{C}$ and added portionwise $\mathrm{NaBH}_{4}(50$ mmol). Then, the reaction product was acidified to $\mathrm{pH} 3$. diluted with water $(400 \mathrm{~mL})$ and extracted with diethyl ether $(250 \mathrm{~mL})$. The combined ethereal laver was washed with brine solution $(200 \mathrm{~mL})$. dried and concentrated under reduced pressure. The cnude product was purified by silica gel column chromatography using $30 \%$ diethyl ether in $n$ hexane containing $1 \%$ glacial acetic acid to afford 3 (8.6 mmol, $48.3 \%$ yield) as a colourless oil.

Production of 13S-HODE using LOX and DMSO. A 
borate buffer solution $(900 \mathrm{~mL} .0 .1 \mathrm{M})$ containing 1 (17.8 munol) and a lipoxygenase enzy me (LOX-lB) ( $100 \mathrm{mg}$ ) was stirred and bubbled with oxygen. The mixture was then cooled at $0^{\circ} \mathrm{C}$ and was then added portionwise DMSO ( 100 $\mathrm{mL}$ ). The reaction product was monitored by GC. After incubation. the suspension was acidified to $\mathrm{pH} 3$ and extracted with diethyl ether $(250 \mathrm{~mL})$. The combined ethereal layer was dried and exaporated under reduced pressure to afford the crude hydroperoxide 2 . The lydroperoxide was dissolved in methanol $(100 \mathrm{~mL})$, cooled at $0{ }^{\circ} \mathrm{C}$ then reduced with $\mathrm{NaBH}_{1}(0.05 \mathrm{~mol})$. The methunolic solution was acidified to $\mathrm{pH} 3$. diluted with distilled water $(100 \mathrm{~mL})$ and extracted with dietlyyl ether $(100 \mathrm{~mL})$. The solvent extract was dried and then evaporated under reduced pressure. Purification using silica gel column chromatography with 30 $\%$ diethyl ether in hexane containing $1 \%$ glacial acetic acid afforded 13S-HODE 3 as a colourless oil ( 10.0 numol. $56.2 \%$ ).

Production of 13S-HODE using immobilized LOX. The immobilized soybean lipoxygenase type lB (100 mg) on acrylic oxirane beads $(5 \mathrm{~g})$ was prepared according to the method previously reported. "The enzy me was suspended in $0.1 \mathrm{M}$ borate buffer $(800 \mathrm{~mL})$ which was stirred and cooled at $0^{\circ} \mathrm{C}$. While stirring, the enzyme suspension was bubbled with oxygen and the emulsion of 1 (17.8 mmol) in $0.1 \mathrm{M}$ borate buffer $(200 \mathrm{~mL})$ was added portionwise. The reaction product was monitored by GC. After $2 \mathrm{~h}$ the reaction misture was acidified to $\mathrm{pH} 3$. Saturated with sodium chloride and extracted with diethyl ether $(250 \mathrm{~mL})$. The ethereal layer was dried and concentrated in vacho. The residue was dissolved in methanol $(100 \mathrm{~mL})$. cooled at $0^{\circ} \mathrm{C}$ and reduced with $\mathrm{NaBH}_{\text {I }}(50 \mathrm{mmol})$. The reaction product was acidified to $\mathrm{pH} 3$, diluted with water $(400 \mathrm{~mL})$ and extracted with dietlyyl ether $(250 \mathrm{~mL})$. The combined ethereal layer was dried and then concentrated under reduced pressure. The cnude product was purified by silica gel column chromatography using $30 \%$ diethyl ether in $n$-hexane containing $1 \%$ glacial acetic acid to afford 3 ( $10.6 \mathrm{mmol} .59 .6 \%$ yield) as a colourless oil.

Production of 13S-HODE using immobilized LOX and
DMSO. The soybean lipoxy genase type $\mathrm{IB}$ was immobilized on oxirane acrylic beads as described earlier ${ }^{\text {T }}$ The filtered immobilized LOX IB ( $100 \mathrm{mg}$ ) on the oxirane acry lic beads $(3 \mathrm{~g})$ was suspended in $0.1 \mathrm{M}$ borate buffer $(1000 \mathrm{~mL}$. $\mathrm{pH}$ 9.5), cooled at $\left(0^{\circ} \mathrm{C}\right.$ and oxygen was bubbled into the mixture. The cooled suspension was stirred and added portionwise the emulsion of 1 (17.8 mumol in $200 \mathrm{~mL}$ of $0.1 \mathrm{M}$ borate buffer) followed by the addition of DMSO $(100 \mathrm{~mL})$. The stiming was continued for $2 \mathrm{~h}$ and the conversion of linoleic acid 1 to 2 was monitored by GC. After incubation. the suspension was acidified to $\mathrm{pH} 3$ and extracted with dietlyy 1 ether $(250 \mathrm{~mL})$. The combined ethereal layer was dried and concentrated under reduced pressure. The residue was dissolved in methanol $(100 \mathrm{~mL})$, cooled at $0^{\circ} \mathrm{C}$ and reduced with sodium borohydride $(0.05 \mathrm{~mol})$. The methanolic solution was acidified to $\mathrm{pH} 3$, diluted with distilled water $(100 \mathrm{~mL})$ and extracted with diethyl ether $(100 \mathrm{~mL})$. The ethereal layer was dried and concentrated in racao. Purification using silica gel columu chromatography with $30 \%$ dietlyl ether in hexane containing $1 \%$ glacial acetic acid afforded 3 as a colourless oil (12.2 nmol. 68.5\%).

\section{References}

1. Kilara. A. Process Biochem. 1985. 20.35.

2. Blondin. G. A. Lhn A. Y. Lcad Sci. 1975. 264.98.

3. Buchanan. M. R.: Halas. T. A.: Lagarde. M.: Guichardant. M. J. Biol. Chem. 1985, 260, 16056

4. Kato, T: Yamaguchi, Y.: Hirano. T.: Yokosama, T.: Uychara. T.: Namai, T.: Yamanaka, S.: H Tarada, N. Chem. Letr. 1984. 409.

5. Kolatukudy. 1'. E.: Wulton. I. J.: Kushwaha. R. P. S. Biochem. Biophys Res (ommon 1971. f. 73 ).

6. Maguire. N. M.: Mahon. M. F.: Molloy K. C.: Read. S.: Roberts. S. M.: Sik, V. J. Chem. Soc Perkin Troms. 1991.2054

7. Gardner. II. W.: Nenton. I. W. Phyochemistry 1987. 26.621

8. Iacazio, G.: I angrand, G.: Baratti, I.: Buono. G.: Triantaphylides. C. J. Org (Tem 1990, 55. 1690.

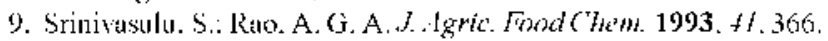

10. Srinivasulu. S.: Rao. A. G. A. J. Igric. Food ( $h e^{2} m .1995$. f3. 562.

11. Fimken, F. A. Dutton, II. I. JAOCS 1971, $48,324$.

12. Onar. M. N. fft Thesis: J iverpool John Moores University: IJK. 2000 